\title{
Gender Mainstreaming In the Leadership Perspective at the Regional Government Agencies Level \\ Hesty Tambajong. ${ }^{1}$ and Zulfan Nahruddin. ${ }^{2}$
}

${ }^{1}$ Public Administration, Musamus University of Merauke, Jl. Kamizaun Mopah Lama, Rimba Jaya, Merauke Regency, Papua 99611 , Indonesia.

${ }^{2}$ Government Science, Muhammadiyah University of Makassar, Jl. Sultan Alauddin No.259, Gn. Sari, Rappocini, Makassar City, South Sulawesi, 90221, Indonesia

*Corresponding Author

Hesty Tambajong

\begin{abstract}
Gender mainstreaming is important in the national development process, especially those related to aspects of leadership in order to realize gender equality in development. The purpose of this study is to analyze Gender Mainstreaming in a Leadership perspective at the Regional Government Agencies level. This research method uses a qualitative descriptive approach. Activities in data analysis in this study were carried out based on data reduction, data display, and conclusion stages. The results showed that the fairness aspect showed that there was no special treatment between men and women in the placement of structural positions / positions in the Regional Government Agencies of Makassar City. From the aspect of justice shows that if there is a deviation carried out by the State Civil Apparatus (ASN) it will be subject to sanctions based on the mechanism applied and from the Equity aspect showing the freedom of opinion and giving aspirations not limited by sex but all opinions can be delivered openly while having good contribution to work. In typical focused leadership there were no problems related to gender and gender privileges to occupy leadership positions, this was due to consideration of the capacity of individuals to become leaders as well as typical communicative leaders supporting gender mainstreaming from an equity aspect showing men and women getting equal opportunities to channel opinions or aspirations to the leadership. but the most prominent typical of some typical leadership is that communication leadership is highlighted by women, this can be seen from the coordination carried out with other employees. While men emphasize typical trust lesdership and respectful leadership.

Keywords: Gender Mainstreaming, Leadership, Organizations, Work Units.
\end{abstract}

\section{INTRODUCTION}

Gender mainstreaming in development focuses on increasing the role of women in development. This field is built on the basis of women's problems rooted in the low quality of women's resources which causes them to be unable to compete with men in society including in terms of women's role in development (Sen \& Grown, 2013).

Leadership is an interesting issue when it is associated with gender mainstreaming. This condition is because leadership contains human behavior that does not only talk about followers but also central figures as a driver behind the achievement of organizational goals (Eagly \& Johnson, 1990; Ford, 2006; Chin, et al., 2008). Leadership has long been regarded as natural. Many views that connect the ability of individuals in leadership are related to the biological aspects inherent in themselves the leader is based on sex differences between men and women.

Development programs in Indonesia are designed to accommodate the public interest but in practice have different impacts between men and women which are not realized is a process that involves many people and stages that are not always profitable in a gender perspective in terms of program planning (Robinson \& Bessell, 2002; Beard \& Cartmill, 2007).

Therefore Gender Mainstreaming is one of the strategies to overcome gender inequalities in order to realize gender equality in various fields of development. as one of the strategies that needs to be implemented by the central and regional governments so that gender issues can be resolved, including in terms of leadership

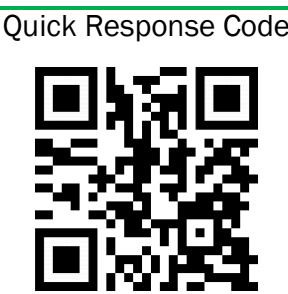

Journal homepage: http://www.easpublisher.com/easjhcs/

Article History

Received: 15.03.2019

Accepted: 28.03.2019

Published: 19.04 .2019
Copyright @ 2019: This is an open-access article distributed under the terms of the Creative Commons Attribution license which permits unrestricted use, distribution, and reproduction in any medium for non commercial use (NonCommercial, or CC-BY$\mathrm{NC})$ provided the original author and source are credited. 
that can be highlighted as having a relationship with Gender Mainstreaming.

Explanation of Gender Mainstreaming (PUG) in Permendagri No. 15 of 2008 concerning General Guidelines for Gender Mainstreaming in the Regions but not for a long time the PUG perspective progressed in terms of regulation, this can be seen through the issuance of the Republic of Indonesia Minister of Home Affairs Regulation Number 67 of 2011 concerning Amendments to Minister of Home Affairs Regulation No. 15 of 2008 About the General Guidelines for Gender Mainstreaming in the Region. In the regulation it was stated that Gender is a concept that refers to the differentiation of roles and functions of men and women that occur due to changing social and cultural conditions of the community. Gender Mainstreaming in the regions is a strategy built to integrate gender into men and women. Mainstreaming is an effort or strategy that must be carried out to provide opportunities for all components to play an optimal role in development (Tyagi \& Das, 2017). Gender mainstreaming in all national development processes is deemed necessary to improve position, role and the quality of women, as well as efforts to realize gender equality and justice in the perspective of leadership in organizations.

Gender Mainstreaming aims to involve men and women in addressing their problems related to development, reforming institutions to build equal rights and opportunities, and encouraging economic development that strengthens equality of participation. Such an approach aims to improve the gaps that continue to exist regarding access to natural resources and the ability to express opinions. The main principle in PUG is fairness, justice and equity (Dewi, 2006)

Through this research, it provides an in-depth picture of Gender Mainstreaming (PUG) in the Regional Government Agencies through three main aspects of PUG, namely Fairness, Justice (Law Enforcement), then Equity from that point of view which can be identified with typical leadership based typical leadership criteria according to Ali (2013), such as Focused leadership, Communication leadership, Trust lesdership, Respectful leadership, Risk leadership. Therefore the purpose of this study is to analyze Gender Mainstreaming in a Leadership perspective at the Regional Government Agencies level.

\section{RESEARCH METHODS}

The research method used is a qualitative descriptive approach with a focus on Gender Mainstreaming in a Leadership perspective at the level of Regional Work Units in Makassar City. Data collection is done by first examining secondary data, then proceed with conducting in-depth interviews with informants selected purposively both from the State Civil Apparatus (ASN) in the Scope of Regional Work Units of Makassar City. Activities in qualitative data analysis are carried out interactively and run continuously and to completion, so that the data is saturated (Huberman \& Miles, 2002). Activities in data analysis in this study are based on data reduction, data display, and conclusion.

\section{RESULTS AND DISCUSSION Fairness}

In this research, fairness is defined as placing individuals as whole people where men and women have the same rights in getting opportunities both in structural positions and career paths. From the interview results, it was explained that in the Regional Work Units of the City of Makassar, the leader or head of the agency assessed that the provision of a position in the structural work unit was determined by the performance and experience of an employee without any gender and male differences. The results of the interview showed that there was no special treatment between men and women in placing structural positions in the Regional Work Units of Makassar City.

Based on the results of interviews, it can be seen that equity in relation to gender mainstreaming cannot necessarily be generalized because it follows the existing rules according to the career pattern or career path of an ASN. From the presentation of the results of the interview can be obtained an understanding that fairness puts individuals as whole people where men and women have the same rights in getting opportunities both in structural positions, career paths, and so on at the Regional Work Units of Makassar City based on existing rules, namely adjusted based on career paths or career patterns and supported by the experience of an employee to occupy a certain position in an agency especially in the Regional Work Units of the City of Makassar so that it can be seen that men and women have equal opportunities to pursue careers as ASNs based on their career path and support of experience and dedication and level of education.

\section{Justice}

In this study Justice or law enforcement is defined as placing individuals as whole people where men and women have equal rights in obtaining legal protection. Based on the results of the interview it can be seen that in the aspect of Justice (Law Enforcement) there is no different treatment between men and women in terms of law enforcement. law enforcement in relation to gender mainstreaming regardless of gender where if there is a deviation carried out by the ASN, sanctions will be imposed based on the mechanism applied starting from reprimand, delaying promotion or the heaviest sanctions, namely dismissal with disrespect.

\section{Equity}

The equity in this study saw the position of women having the right to voice their aspirations and needs in the Regional Work Units of the City of 
Makassar intended in this study that women have the right to write their needs equally to men, including the ability to participate in the public arena by contributing to the work done. In giving opinions or aspirations of men more dominant, but because the number of men in the Regional Work Units of the City of Makassar is more numerous and the number of heads of fields is also more male dominated, it is stated that there is no limit given based on gender aspirations contributing to meetings and activities carried out still receive the same attention. Freedom of opinion and giving aspirations are not limited by sex but all opinions can be expressed openly as long as they have a good contribution to the work done.

Next to provide an overview of the typical leadership in gender mainstreaming based on three aspects, namely Fairness, Justice and Equity. Then it will be parsed and identified through the following criteria:

\section{Focused Leadership}

For focused leadership criteria, leaders can be interpreted in all activities trying to attract the attention of followers, on important issues in the Regional Work Units of Makassar City. The ability of leaders to attract the attention of their followers encourages to embrace all employees or staff in a body or field that is a lower leader, criteria or typical leadership focused leadership has not emerged as a typical gender mainstreaming. Furthermore, in a typical focused leadership issues about gender mainstreaming have never been the focus of attention because they have been understood by each individual in the Regional Work Units of Makassar City. Furthermore, issues regarding gender mainstreaming can be understood by each individual so that there are no problems related to gender and gender privileges to occupy leadership positions because of the capacity of individuals to become leaders.

\section{Communication Leadership}

In communicative leadership criteria are interpreted as leaders using the ability to communicate effectively, including actively listening to suggestions from followers or subordinates in the organization as feedback to get constructive ideas at the Regional Work Units of Makassar City.

From the results of the interview, the communicative leadership provided communication space in terms of gender mainstreaming from the Equity aspect, namely women have the right to voice their aspirations and needs at the Regional Work Units of Makassar City. Based on the results of the interview, it can be seen that typical communicative leaders support gender mainstreaming from the equity aspect where men and women have the same opportunity to channel their opinions or aspirations to the leadership.

\section{Lesdership Trust}

In this study the typical trust lesdership is the behavior of leaders who can foster trust, and be consistent in their actions and keep promises. The establishment of trust can be caused by two things, namely first, consistency, which is consistent in attitude and behavior; Second, credibility, namely trust that is built on a one-do attitude that says one will do to the Regional Work Units of Makassar City.

Typical leadership that is believed to prioritize consistency and credibility needs to be traced in relation to gender mainstreaming where typical leadership like this supports fairness, namely placing individuals as whole people where men and women have equal rights in getting opportunities both in structural positions, career paths, etc.

Based on the results of interviews, it can be seen that equal rights to each employee to get the opportunity to occupy a wide open position. This is supported by leaders who gain trust by employees. For typical trust lesdership leadership in relation to gender mainstreaming, it appears that male leadership is more trusted than women. Based on the results of interviews, it can be seen that the trust lesdership is still more male dominant, seen from the number of leaders who are the heads of parts and fields in several Regional Work Units of Makassar City.

\section{Respectful Leadership}

In this respectful leadership study, activities are carried out by a leader who shows concern and affection for the leader, such as giving appreciation for the achievements of his followers. Typical respected leadership in several Regional Work Units of Makassar City.

Based on the results of interviews, it can be obtained an understanding that typical respected leadership shows appreciation for employees who do work well and effectively regardless of men or women getting the same appreciation by the leadership or head of the agency.

From the results of interviews, it can be seen that gender mainstreaming from the aspect of Justice (Law Enforcement) is placing individuals as whole people where men and women have the same rights in obtaining legal protection and giving legal sanctions to the Regional Work Units of Makassar City. It can be seen that there is no gender side if there are violations committed by employees both disciplinary and the use of authority.

\section{Risk Leadership}

In risk leadership research, leaders who dare to take risks to involve and give great responsibility to followers (subordinates) to carry out activities designed by leaders, with the intention to foster a strong 
commitment in achieving organizational goals in the Regional Work Units of Makassar City. Based on the results of the interview, it can be seen that there are aspects of Fairness and equity where the leader gives responsibility for each employee who is considered capable of holding trust or responsibility regardless of gender or gender.

But things that can be observed from gender mainstreaming from aspects of Fairness and equity are constrained by women's responsibility in personal life. Based on the results of the interview, it can be seen that the aspects of equality and equality in gender mainstreaming have actually been implemented, but in the implementation it does not really emphasize women in ASN careers because the concentration of work between households is divided so it is not surprising if the strategic position of the Regional Work Units is filled with men.

Based on the results of the interview, it can be seen that typical leadership for more communicative female leadership is considered capable of coordinating well while typical leadership owned by men in several Regional Work Units in Makassar City, both the head of body and head of department / field are considered to be more leadership and also typical of respected leadership.

Based on the results of interviews, it can be obtained an illustration that the typical leadership that is expected is leadership that is able to focus on established policies and focuses on the responsibilities given. From a series of interview results, it was understood that typical leadership in terms of gender mainstreaming has a varied view but the most prominent of some typical leadership is that communicative leadership is more highlighted by women, this can be seen from the coordination with other employees. While men emphasize more typical leadership that is trusted and respected.

The explanation stated is typical of leadership in gender mainstreaming (PUG). If you look at the PUG concept, it is meant a strategy to reduce gender inequalities and achieve gender equality by using a gender perspective in the development process Gender mainstreaming is a process to ensure women and men have access and control over resources, obtain development benefits and make decisions that the same at all stages of the development process and all projects, programs and government policies (Pearson, 2005).

Gender mainstreaming in all national development processes is deemed necessary to realize gender equality and justice (Gizelis \& Krause, 2015). In terms of leadership, it cannot be separated from the fact that the effect of one direction occurs because the leader may have certain qualities that distinguish him from his followers regardless of gender, but related to the concept of PUG seen from the three aspects of equity, law enforcement and equality received apply to the Regional Work Units of the City of Makassar, although in terms of structural strategic positions such as the head of the sub-sector or sub-sector are more maledominated, this is because there are more male employees and men are more focused on work than women who choose to divide the focus is on matters other than office work but the PUG aspect here is not ignored. This can be seen from the leadership that has a typical communicative able to accommodate all kinds of interests and aspirations from subordinates regardless of male or female gender.

\section{CONCLUSION}

In the aspect of fairness there is no special treatment between men and women in the placement of structural positions / positions in the Regional Work Units of Makassar City. From the aspect of Justice, if there are deviations made by the ASN, sanctions will be imposed based on the mechanism applied and from the equity aspect the freedom to express opinions and give aspirations is not limited to sex, but all opinions can be expressed openly as long as they have a good contribution to the work. In typical focused leadership there were no gender related issues and no gender privileges to occupy leadership positions, this was due to consideration of the capacity of individuals to become leaders as well as typical communicative leaders supporting gender mainstreaming from the equity aspect where men and women had equal opportunities to channel opinions or aspirations to the leadership. but the most prominent typical of some typical leadership is that communication leadership is highlighted by women, this can be seen from the coordination carried out with other employees. While men emphasize typical trust lesdership and respectful leadership.

\section{REFERENCES}

1. Ali, M. E. (2013). Kepemimpinan Integratif dalam Konteks Good Governance. Jakarta: PT. Multicerdas Publishing.

2. Beard, V., \& Cartmill, R. (2007). Gender, collective action and participatory development in Indonesia. International Development Planning Review, 29(2), 185-213.

3. Chin, J. L., Lott, B., Rice, J., \& Sanchez-Hucles, J. (Eds.). (2008). Women and leadership: Transforming visions and diverse voices. John Wiley \& Sons.

4. Dewi, S. R. (2006). Pengarusutamaan Gender. Jurnal Perempuan, Edisi 50. Jakarta : Yayasan Jurnal Perempuan.

5. Eagly, A. H., \& Johnson, B. T. (1990). Gender and leadership style: A meta-analysis. Psychological bulletin, 108(2), 233.

6. Ford, J. (2006). Discourses of leadership: Gender, identity and contradiction in a UK public sector organization. Leadership, 2(1), 77-99. 
7. Gizelis, T. I., \& Krause, J. (2015). Exploring gender mainstreaming in security and development. Gender, Peace and Security: Implementing UN Security Council Resolution, $1325,165-85$.

8. Huberman, M., \& Miles, M. B. (2002). The qualitative researcher's companion. Sage.

9. Pearson, R. (2005). The rise and rise of gender and development. A radical history of development studies: individuals, institutions and ideologies, 157-79.

10. Robinson, K. M., \& Bessell, S. (Eds.). (2002).

Women in Indonesia: Gender, equity and development (Vol. 8). Institute of Southeast Asian Studies.

11. Sen, G., \& Grown, C. (2013). Development crises and alternative visions: Third world women's perspectives. Routledge.

12. Tyagi, N., \& Das, S. (2017). Gender mainstreaming in forest governance: analysing 25 years of research and policy in South Asia. International Forestry Review, 19(2), 234-244. 